\title{
Zastosowanie transformaty Fouriera do ultradźwiękowej oceny połączeń klejowych
}

\section{Fourier transform application to ultrasonic evaluation of glued joints}

\section{Streszczenie}

W artykule przedstawiono metodę oceny połączeń klejowych za pomocą transformaty Fouriera. Podstawowymi parametrami widma impulsu ultradźwiękowego, które mogą być akustyczną miarą jakości połączenia, są: pasmo przenoszenia oznaczane jako B oraz częstotliwość maksymalnej amplitudy oznaczana jako $f_{r}$.

W badaniach wykorzystano próbki wykonane ze stali 45 połączone za pomocą kleju cyjanoakrylowego Loctite 496. Powierzchnie próbek przygotowano na kilka sposobów, tak aby zróżnicować wytrzymałość połączeń. Na podstawie wyników badań wyznaczono wartości współczynnika korelacji między parametrami ultradźwiękowymi w dziedzinie częstotliwości a mechaniczna miara jakości połączeń.

\section{Wstęp}

Kleje to substancje chemiczne zdolne do trwałego łączenia materiałów jedno- i różnorodnych, zapewniającego szczelność połączenia i równomierny rozkład naprężeń w całym jego obszarze. Łączenie odbywa się w wyniku oddziaływania sił adhezji właściwej, adhezji mechanicznej i sił spójności kleju - kohezji. Proces ten nie wymaga trudnych procesów obróbki mechanicznej, są one najczęściej ograniczone do piaskowania lub śrutowania powierzchni przeznaczonych do łączenia w celu usunięcia zanieczyszczeń, np. produktów korozji, oraz do jej odtłuszczenia.

Dr inż. Jakub Kowalczyk, mgr inż. Dariusz Ulbrich, dr hab. inż. Marian Jósko prof. PP, dr inż. Ryszard Mańczak - Politechnika Poznańska.
Klejenie jest technologią, która przeżywa swój renesans i rozwija się niezwykle dynamicznie, znajdując zastosowanie praktycznie we wszystkich gałęziach przemysłu. Szerokie zastosowanie połączeń klejowych obserwuje się zwłaszcza w przemyśle motoryzacyjnym.

Wraz z rozwojem klejenia i częściowym wypieraniem tradycyjnych metod łączenia, takich jak zgrzewanie, pojawił się problem kontroli, a w szczególności badań nieniszczących tych połączeń. Wśród metod nieniszczących oceny połączeń klejowych największe zastosowanie mają takie metody, jak: wizualna, ultradźwiękowa, rezonansowa, termograficzna oraz holografia optyczna $[1,6]$.

\section{Metoda ultradźwiękowa}

Spośród stosowanych metod najszersze zastosowanie może mieć metoda ultradźwiękowa. Jest ona 
skutecznie wykorzystywana do wykrywania nieciagłości w różnych materiałach. Obserwowany jest także wzrost zainteresowania tą metodą w badaniach naukowych oraz poszerzenie zakresu jej przemysłowego wykorzystania i stosowanych w niej technik kontrolnych poza klasyczne badania ultradźwiękowe np. odlewów, odkuwek czy połączeń spawanych [2, 3]. Zastosowanie ultradźwięków w defektoskopii, również w odniesieniu do połączeń adhezyjnych, zostało opracowane przez J. Deputata [4].

W badaniach połączeń spajanych możliwe jest prowadzenie kontroli jakości połączeń zgrzewanych punktowo i połączeń adhezyjnych, w tym lutowanych i klejonych oraz połączeń powłoka-podłoże. Metoda ta umożliwia ponadto pomiary naprężeń i twardości części maszyn. Obecnie prowadzone badania ultradźwiękowe wybranych obiektów umożliwiają ich kontrolę w obszarze do $20 \mathrm{~m}$ od miejsca przyłożenia głowicy ultradźwiękowej.

Wybrane parametry impulsów fali ultradźwiękowej, użytej do badania połączeń klejowych, mogą być przydatne do oceny ich jakości. Parametry te wynikają z uzyskiwanych na ekranie aparatu ultradźwiękowego układów impulsów ultradźwiękowej fali podłużnej. Korzystnym do oceny tych połączeń układem impulsów ultradźwiękowych jest taki układ, w którym uzyskuje się dwa echa dna, podobnie jak w metodzie wyznaczania ciśnieniowego współczynnika odbicia. Silne tłumienie warstwy kleju zazwyczaj uniemożliwia uzyskanie drugiego echa dna. Układ impulsów ultradźwiękowych z tylko jednym echem dna jest również układem przydatnym do oceny połączenia klejowego, ponieważ zawiera - oprócz syntetycznej informacji o jakości pierwszego połączenia adhezyjnego - dane na temat drugiego połączenia i kohezji warstwy klejowej.

\section{Transformata Fouriera}

Analizując zagadnienia związane z oceną wielowarstwowych połączeń klejowych przy wykorzystaniu transformaty Fouriera, przytoczono wyniki uzyskane podczas wykonywania badań połączeń klejowych przez A.F. Browna [5]. Z przeprowadzonej analizy wynika, iż ocena połączeń klejowych z wykorzystaniem transformaty Fouriera jest stosunkowo łatwa.

Wykorzystanie analizy częstotliwościowej w badaniach ultradźwiękowych jest podejściem często stosowanym, pomimo trudności z oceną, identyfikacją i interpretacją uzyskiwanych obrazów na ekranie aparatu ultradźwiękowego oraz niewielkich różnic między uzyskiwanymi obrazami widm. Aby móc przeprowadzić analizę częstotliwościową impulsów ultradźwiękowych, niezbędne jest uzyskanie pełnego niewyprostowanego impulsu fali ultradźwiękowej. Przykładowy impuls ultradźwiękowy w dziedzinie czasu, uzyskany w badaniach własnych, który poddano transformacie Fouriera, przedstawiono na rysunku 1.
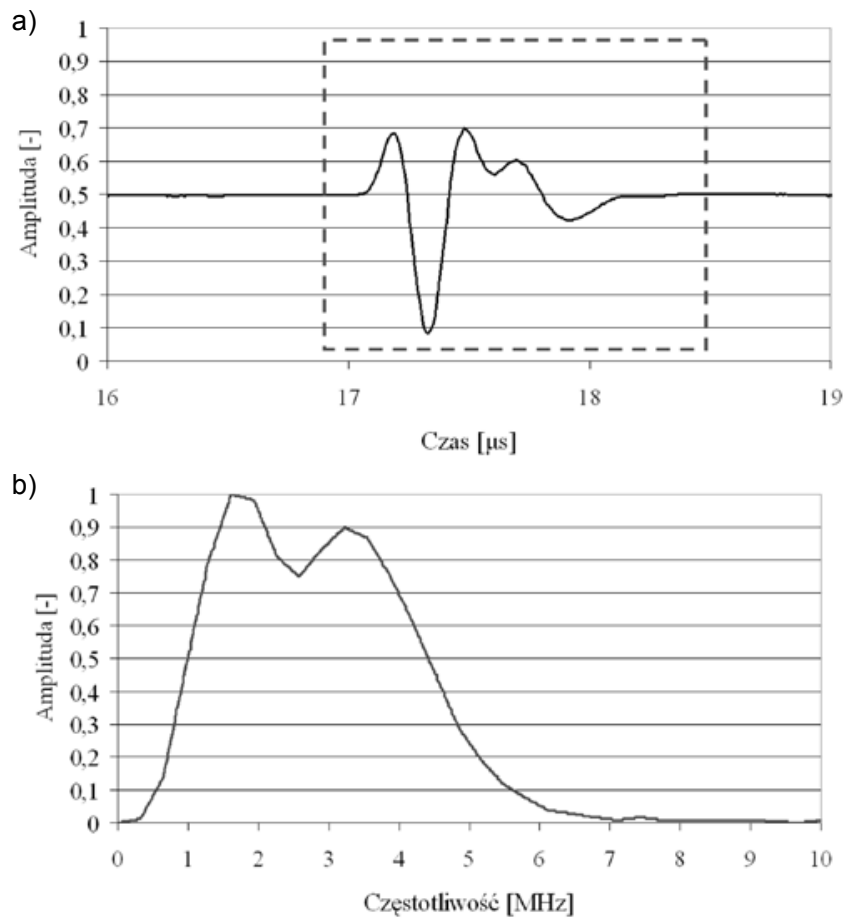

Rys. 1. Transformata Fouriera wybranego impulsu ultradźwiękowego z obszaru połączenia klejowego w funkcji czasu [6]: a) impuls ultradźwiękowy w funkcji czasu, b) obwiednia widma impulsu ultradźwiękowego

Fig. 1. The Fourier transform of the selected ultrasonic pulse from the adhesive joint in the time domain [6]: a) an ultrasonic pulse in the time domain, $b$ ) the spectrum envelope of the ultrasonic pulse

Podstawowymi parametrami widma impulsu ultradźwiękowego, które mogą być akustyczną miarą jakości połączenia, są: pasmo przenoszenia oznaczane jako B oraz częstotliwość maksymalnej amplitudy oznaczana jako $f_{r}$. Pasmo przenoszenia oznacza szerokość impulsu, wyrażoną w Hz przy spadku amplitudy o $6 \mathrm{~dB}$.

W badaniach podjęto próbę wykorzystania jako miary jakości połączeń klejowych także innych parametrów impulsów ultradźwiękowych widma amplitudowo-częstotliwościowego, np. ciśnienia widma impulsu fali ultradźwiękowej w zakresie niskich częstotliwości - do początku pasma przenoszenia (niskoczęstotliwościowe ciśnienie impulsu - $P_{a}$ (rys. 2), ciśnienia widma impulsu fali ultradźwiękowej w zakresie częstotliwości pasma przenoszenia (średnioczęstotliwościowe ciśnienie impulsu $-P_{b}$ ) oraz ciśnienia widma impulsu fali ultradźwiękowej w zakresie wysokich częstotliwości - powyżej końca pasma przenoszenia (wysokoczęstotliwościowe ciśnienie impulsu $-\mathrm{P}_{\mathrm{c}}$ ). Dodatkowo, w badaniach wykorzystano częstotliwości początku $\left(B_{1}\right)$ i końca pasma przenoszenia $\left(B_{2}\right)$, nazywane dolną i górną granicą częstotliwości.

Wybór parametrów widma impulsu fali ultradźwiękowej do oceny jakości połączeń klejowych był podyktowany zauważonymi zmianami widma odpowiadającymi zmianom stanu połączenia, obserwowanymi podczas badań rozpoznawczych. 


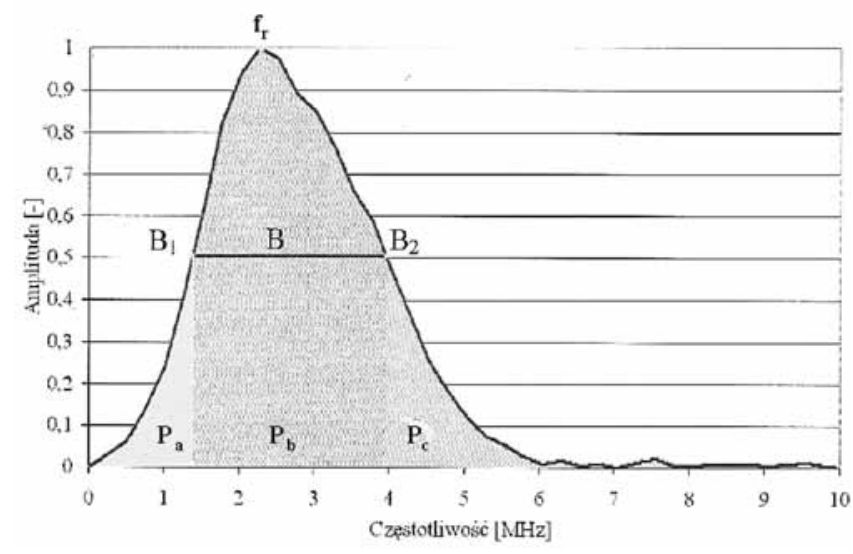

Rys. 2. Widmo impulsu ultradźwiękowego [6]: $f_{r}$ - częstotliwość maksymalnej amplitudy, B - pasmo przenoszenia, $\mathrm{B}_{1}$ - dolna granica częstotliwości, $B_{2}$ - górna granica częstotliwości, $P_{a}$ - niskoczęstotliwościowe ciśnienie impulsu, $P_{b}$ - średnioczęstotliwościowe ciśnienie impulsu, $P_{c}$ - wysokoczęstotliwościowe ciśnienie impulsu

Fig. 2. Ultrasonic pulse spectrum [6]: $f_{r}$ - frequency of maximum amplitude, B - transmitted frequency band, $B_{1}$ - lower frequency limit, $B_{2}$ - upper frequency limit, $P_{a}$ - low-frequency pulse pressure, $P_{b}-$ medium frequency pulse pressure, $P_{c}-$ high frequency pulse pressure

Jakość połączenia klejowego wpływa na wyniki analizy częstotliwościowej fali ultradźwiękowej. Połączenie może oddziaływać na falę jak filtr dolno- lub górnoprzepustowy. W związku z tym, w przypadku badania połączenia klejowego, w którym wystąpią wady, może dojść do większego tłumienia określonych częstotliwości.

\section{Eksperyment}

Celem prowadzonych badań była ocena możliwości zastosowania metody ultradźwiękowej wykorzystującej transformatę Fouriera do oceny połączeń klejowych.

W badaniach wykorzystano próbki stalowe (stal 45) przedstawione na rysunku 3. Do ich wykonania zastosowano klej cyjanoakrylowy Loctite 496. Grubość warstwy kleju we wszystkich próbkach była jednakowa, dzięki zastosowaniu stałego docisku łączonych elementów.

Po wykonaniu krążków przeznaczonych na próbki ich powierzchnie przeznaczone do klejenia przygotowano w taki sposób, aby odtworzyć warunki, jakie

a)

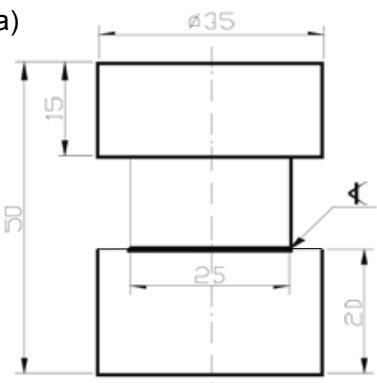

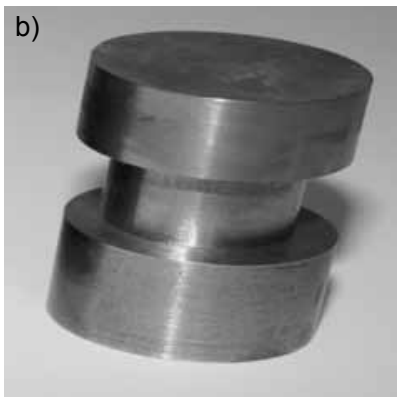

Rys. 3. Próbka do badań: a) schemat, b) widok

Fig. 3. Sample for tests: a) scheme, b) the view of sample mogą wystąpić w czasie wykonywania połączeń klejowych w warunkach przemysłowych. Zbiór krążków został podzielony na grupy, które cechowały się różnym przygotowaniem powierzchni. Powierzchnie zostały zróżnicowane zarówno pod względem obróbki mechanicznej (szlifowanie, piaskowanie), jak i sposobu ich oczyszczenia (wyczyszczenie preparatem Loctite, naniesienie chłodziwa szlifierskiego oraz smaru plastycznego).

W pierwszej serii podczas badań na szlifowane powierzchnie klejone naniesiono smar plastyczny. W drugiej i trzeciej serii badawczej na powierzchnie również poddane szlifowaniu naniesiono odpowiednio chłodziwo szlifierskie oraz olej wykorzystywany do obróbki plastycznej. W czwartej serii badawczej powierzchnie po szlifowaniu zostały oczyszczone w sposób zgodny z wymaganiami producenta kleju. Kolejne dwie serie badań obejmowały próbki piaskowane elektrokorundem EK40, przy czym w pierwszej $z$ nich na powierzchnie naniesiono olej do obróbki plastycznej, a druga została oczyszczona. Dwie ostatnie serie przygotowano podobnie, $z$ tym że do piaskowania użyto elektrokorundu EK60.

Zrealizowano 8 prób badawczych. Po zerwaniu próbek zmierzono siłę, powodującą zniszczenie połączenia. Na podstawie uzyskanej siły obliczono naprężenia rozrywające, które spowodowały rozdzielenie połączenia klejowego.

Zgodnie z założeniem, w wyniku zróżnicowanego przygotowania powierzchni próbek do klejenia, uzyskano różne wartości sił rozrywających. Średnie wyniki naprężeń rozrywających uzyskanych dla ośmiu prób przedstawiono $w$ tablicy I. Pierwsze badania dotyczyły próbek, w których na powierzchnie klejone naniesiono smar plastyczny, natomiast ostatnie próbek, których powierzchnie przeznaczone do klejenia zostały przygotowane zgodnie z wytycznymi producenta kleju.

W badaniach ultradźwiękowych użyto głowicy DS12HB1-6 firmy Karl Deutsch. Głowicę tę wybrano podczas badań rozpoznawczych, w których uzyskano najkorzystniejsze sygnały $z$ wszystkich analizowanych głowic ultradźwiękowych w laboratorium badań nieniszczących. Częstotliwość głowicy wynosi $2,12 \mathrm{MHz}$, co stanowi optymalny zakres częstotliwości dla badania połączeń klejowych. Dla częstotliwości powyżej $6 \mathrm{MHz}$, ze względu na silne tłumienie, nie uzyskano impulsu $z$ dna próbki. We wszystkich próbach wykorzystywano ten sam ośrodek sprzęgający - Echotrace Karl Deutsch. Wyniki badań ultradźwiękowych

Tablica I. Zestawienie średnich wartości naprężeń rozrywających uzyskanych w badaniach właściwości mechanicznych dla poszczególnych serii badawczych

Table I. The mean tensile strength founded out in the mechanical properties tests for separate series

\begin{tabular}{|c|c|c|c|c|c|c|c|c|}
\hline Nr serii & 1 & 2 & 3 & 4 & 5 & 6 & 7 & 8 \\
\hline $\mathrm{R}_{\mathrm{m}}, \mathrm{MPa}$ & 1,04 & 9,23 & 19,31 & 26,47 & 23,01 & 41,40 & 23,91 & 39,56 \\
\hline
\end{tabular}


Tablica II. Zestawienie wartości parametrów impulsów ultradźwiękowych w dziedzinie częstotliwości: $f_{r}$ - częstotliwość maksymalnej amplitudy, B - pasmo przenoszenia, $\mathrm{B}_{1}$ - dolna granica częstotliwości, $B_{2}$ - górna granica częstotliwości, $P_{a}$ - niskoczęstotliwościowe ciśnienie impulsu, $P_{b}$ - średnioczęstotliwościowe ciśnienie impulsu, $\mathrm{P}_{\mathrm{c}}$ - wysokoczęstotliwościowe ciśnienie impulsu

Table II. The ultrasonic pulse parameters values in the frequency domain: $f_{r}$ - frequency of maximum amplitude, $B$ - transmitted frequency band, $B_{1}$ - lower frequency limit, $B_{2}-$ upper frequency limit, $P_{a}$ - low-frequency pulse pressure, $P_{b}-$ medium frequency pulse pressure, $P_{c}$ - high frequency pulse pressure

\begin{tabular}{|c|c|c|c|c|c|c|c|}
\hline \multirow{2}{*}{$\begin{array}{c}\mathrm{Nr} \\
\text { serii }\end{array}$} & \multicolumn{6}{|c|}{ Parametr sygnału w dziedzinie częstotliwości } \\
\cline { 2 - 8 } & $\begin{array}{c}\mathrm{f}_{\mathrm{r}} \\
\mathrm{MHz}\end{array}$ & $\begin{array}{c}\mathrm{B} \\
\mathrm{MHz}\end{array}$ & $\begin{array}{c}\mathrm{B}_{1} \\
\mathrm{MHz}\end{array}$ & $\begin{array}{c}\mathrm{B}_{2} \\
\mathrm{MHz}\end{array}$ & $\mathrm{P}_{\mathrm{b}}$ & $\mathrm{P}_{\mathrm{a}}$ & $\mathrm{P}_{\mathrm{c}}$ \\
\hline 1 & 2,81 & 3,27 & 1,25 & 4,52 & 2,09 & 0,28 & 0,70 \\
\hline 2 & 3,35 & 3,27 & 1,37 & 4,64 & 2,08 & 0,23 & 0,78 \\
\hline 3 & 2,49 & 2,44 & 1,35 & 3,79 & 2,09 & 0,22 & 0,29 \\
\hline 4 & 3,22 & 2,81 & 1,44 & 4,24 & 2,01 & 0,20 & 0,59 \\
\hline 5 & 2,52 & 2,47 & 1,40 & 3,87 & 2,10 & 0,19 & 0,27 \\
\hline 6 & 2,61 & 2,59 & 1,41 & 4,00 & 2,17 & 0,18 & 0,32 \\
\hline 7 & 2,38 & 2,53 & 1,37 & 3,90 & 2,12 & 0,19 & 0,31 \\
\hline 8 & 2,51 & 2,19 & 1,38 & 3,84 & 2,08 & 0,18 & 0,29 \\
\hline
\end{tabular}

\section{Wnioski}

Uzyskane wyniki badań laboratoryjnych pozwalają na ilościową ocenę jakości połączeń klejowych.

Wyznaczono zależności między wybranymi parametrami impulsów ultradźwiękowych analizowanych
Tablica III. Zestawienie współczynników korelacji między parametrem ultradźwiękowym w dziedzinie częstotliwości a mechaniczną miarą jakości połączenia (oznaczenia jak w tabl. II)

Table III. Ultrasonic in frequency domain and mechanical joint quality correlation coefficient (designation acc to table II)

\begin{tabular}{|c|c|c|c|c|c|c|c|}
\hline $\begin{array}{c}\text { Parametr } \\
\text { ultradźwiękowy }\end{array}$ & $\begin{array}{c}\mathrm{f}_{\mathrm{r}} \\
\mathrm{MHz}\end{array}$ & $\begin{array}{c}\mathrm{B} \\
\mathrm{MHz}\end{array}$ & $\begin{array}{c}\mathrm{B}_{1} \\
\mathrm{MHz}\end{array}$ & $\begin{array}{c}\mathrm{B}_{2} \\
\mathrm{MHz}\end{array}$ & $\mathrm{P}_{\mathrm{b}}$ & $\mathrm{P}_{\mathrm{a}}$ & $\mathrm{P}_{\mathrm{c}}$ \\
\hline $\begin{array}{c}\text { Współczynnik } \\
\text { korelacji }\end{array}$ & $-0,40$ & $-0,79$ & 0,73 & $-0,68$ & 0,27 & $-0,90$ & $-0,70$ \\
\hline
\end{tabular}

realizowanych z wykorzystaniem transformaty Fouriera zamieszczono w tablicy II.

Wyznaczono także wartości współczynników korelacji między właściwościami mechanicznymi a parametrami ultradźwiękowymi. Uzyskane wyniki zawarto w tablicy III.

Mimo że współczynniki korelacji dla wybranych parametrów są wysokie, praktyczne zastosowanie wyników badań wymaga prowadzenia dalszych prac badawczych i pełniejszego rozpoznania zachodzących zjawisk fizycznych.

\section{Literatura}

[1] Adams R.D., Drinkwater B.W.: Nondestructive testing of adhesively-bonded joint. NDT\&E International, vol. 30, 1997, 2, s. 93-98.

[2] Cawley P., Allin J.M., Lowe M. J. S.: Adhesive disbond detection of automotive components using first mode ultrasonic resonance. NDT\&E International, vol. 36, 7, 2003, s. 503-514.

[3] Grondel S., Delebre Ch., Assai J et al.: Fatigue crack monitoring of riveted aluminum strap joints by Lamb wave analysis and acoustic emission measurement techniques, NDT\&E International, vol. 35, 3, 2002, s. 137-146.
[4] Deputat J.: Postępy w ultradźwiękowych badaniach materiałów, Część I. Przegląd Mechaniczny, Hz. 21, 1996, s. 5-10.

[5] Pilarski A.: Ocena wytrzymałości adhezyjnej połączeń warstwowych za pomocą metod ultradźwiękowych. Rozprawa doktorska, IPPT PAN, Warszawa, 1983 (biblioteka IPPT PAN).

[6] Kowalczyk J.: Ocena połączeń klejonych metodą ultradźwiękową, Rozprawa doktorska, Politechnika Poznańska, Poznań 2009 (biblioteka Politechniki Poznańskiej).

Część badań wykorzystanych w niniejszym opracowaniu wykonano w ramach projektu promotorskiego NR N N503 130833.

\section{W następnym numerze}

Krzsztof Dutka, Jan Stabryła

Analiza przyczyn niskiej trwałości złącza spawanego wału inspektomatu

Ryszard Pakos

Próba zginania doczołowych złączy spawanych - wymagania podstawowe i alternatywne

Tomasz Piwowarczyk, Aleksandra Małachowska, Paweł Sokołowski

Tendencje rozwojowe zgrzewania łukiem wirującym w aspekcie zastosowań w przemyśle samochodowym

Lesław Sozański, Paweł Sokołowski

Normalizacja wykrywania i oceny powierzchniowych niezgodności spawalniczych

Winnicki Marcin, Małachowska Aleksandra, Sokołowski Paweł

Wpływ stereometrii powierzchni na właściwości adhezyjne warstwy naniesionej metodą LPCS 